\title{
REAKTUALISASI STRATEGI PENDIDIKAN ISLAM: IKHTIAR MENGIMBANGI PENDIDIKAN GLOBAL
}

\author{
M. Sobry \\ (Fakultas Ilmu Tarbiyah dan Keguruan IAIN Mataram \\ E-mail: dr.508ry@yahoo.co.id)
}

Abstract: Globalization is inevitable phenomenon that may cause anxiety amongst countries, such as Indonesia, that still preserve their culture, ethics and religious values because it always introduces new things that are not easily adjusted to regional or local contexts. Globalization as it is reflected in rapid change and transformation in technology has affected most of buman's life, including education. Globalized education is the one that is characterized by global and transnational elements in its basic structure, for example, the use of information technologies and digital media that have both positive and negative impacts. However, for Indonesia, whose majority population is Islam, globalization is not a threat, which should be evaded. What needs to do is to integrate Islamic concepts and values in it. Globalization and its type of education that looks contrary to religious norms will no longer become a menace if it is strengthened with religious values.

Abstrak: Globalisasi merupakan fenomena kekinian yang terkadang dipandang sebagai momok dalam konteks bangsa, seperti Indonesia, yang berhasrat kuat melestarikan nilai adat, budaya, moral, dan nilai agama. Tulisan ini mencermati globalisasi yang memengarubi dunia pendidikan sebagaimana terlihat pada semakin luasnya penggunaan media digital dengan semua manfaat dan mudarat yang menyertainya. Penulis berpendapat bahwa fenomena itu semestinya dipandang wajar dan dihadapi dengan lapang dada. Namun ia harus diimbangi dengan konsep-konsep islami dan diperkuat dengan strategi islami pula. Islam memiliki konsep moralitas dan etika yang komprehensif untuk diaktualisasikan dalam konteks arus globalisasi. Oleh karena itu, tidak ada jalan lain untuke mengimbangi pendidikan global saat ini kecuali dengan kembali kepangkuan konsep-konsep pendidikan Islam.

Keywords: Strategi pendidikan Islam, globalisasi, tujuan pendidikan Islam, pendidikan ala Rasulullah. 
GLOBALISASI telah menjalar tanpa mampu dibendung, bahkan sudah menjadi sunnatullah. Memaknai globalisasi tidak selalu negatif. Ia pun akan bernilai positif bila dimainkan dengan baik dan benar. Namun yang banyak muncul ke permukaan adalah "nilai negatif". Globalisasi telah menjadi "kambing hitam" dalam setiap kemerosatan moral yang dihadapi suatu bangsa. Ia diklaim sebagai "biang kerok" terjadinya malapetaka yang menjamah halhal yang bersifat tabu. Di sisi yang berbeda, globalisasi diamini mampu membuka mata kita, bahwa dunia demikian luas. Ada banyak ilmu yang dapat dikonsumsi secara gratis sebagai studi banding terhadap apa yang kita miliki.

Globalisasi layaknya pisau yang dapat bernilai positif atau negatif tergantung orang yang menguasainya. Salah satu jalan untuk menguasai dan mengendalikannya adalah pendidikan Islam. Diakui atau tidak, pendidikan Islam memegang kendali penting dalam mempertahankan kelanggengan kehidupan sosial, yaitu mampu hidup konsisten mengatasi ancaman dan tantangan masa depan. Dalam konteks Islam, al-Attas, seorang pemikir pendidikan muslim—sebagaimana yang dikutip Tafsirmenyatakan bahwa secara umum tujuan pendidik adalah menjadikan manusia sebagai hamba Allah yang baik. ${ }^{1}$ Hamba Allah yang baik dapat dimaknai variatif meliputi kebaikan dalam bentuk abstrak seperti selalu berpikir positif, mengedepankan rasio, memiliki motivasi kerja yang tinggi dan sebagainya, dan dalam bentuk konkret seumpama perilaku mulia dalam setiap tutur dan perbuatan, bekerja keras dan mengembangkan diri melalui kreativitas-kreativitas positif. Lebih spesifik, Al-Abrasyi dalam Tafsir merinci tujuan akhir pendidikan sebagai berikut: 1) pembinaan akhlak; 2) menyiapkan anak didik untuk hidup di dunia dan akhirat; 3) pengusaan ilmu pengetahuan, dan 4) keterampilan bekerja. ${ }^{2}$ Sehingga tujuan utama pendidikan adalah mempersiapkan peserta didik menjadi insan yang memiliki akhlak mulia, memiliki motivasi, dan etos kerja tinggi yang dikembangkan melalui kreativitas-kreativitas positif.

${ }^{1}$ Ahmad Tafsir, Ilmu Pendidikan dalam Perspektif Islam (Bandung: Remaja Rosdakarya, 1994), 46.

IIbid., 48. 
Melihat tujuan pendidikan di atas, pendidikan Islam sebagai bagian dari struktur kelembagaan Islam memiliki kaitan fungsional dengan nilai dan moral Islam, yang berperan penting dalam mengarahkan proses pendidikan dalam setting perubahan sosial yang islami. Perubahan tersebut tidak hanya diorientasikan pada hasil-hasil kuantitatif, tetapi juga perubahan yang berpijak di atas kerangka etika dan moral Islam. Oleh karena itu, pendidikan Islam harus mulai berbenah diri dengan menyusun strategi global tanpa meninggalkan nilai-nilai islami dalam pendidikan, baik dari segi teoretis maupun praktis, sehingga pendidikan Islam tetap eksis dan dapat berkolaborasi-integratif dengan tuntutan global.

\section{Strategi Pendidikan Islam: Menegaskan Kembali Tujuannya}

Keberhasilan proses pendidikan ditentukan oleh banyak faktor, salah satu faktor terpenting yang kadang dilupakan adalah strategi. Secara bahasa, strategi bisa diartikan sebagai siasat, kiat, trik atau cara. Secara umum strategi ialah suatu garis besar haluan dalam bertindak untuk mencapai tujuan yang telah ditentukan. Dengan mengetahui strategi, diharapkan dapat membantu memudahkan pendidik dalam melaksanakan tugasnya. Kegiatan yang dilakukan tanpa strategi, berarti kegiatan tersebut dilakukan tanpa acuan dan arah yang jelas. Kegiatan tersebut dapat menyebabkan terjadinya penyimpanganpenyimpangan (malapraktik pendidikan), yang pada gilirannya bisa mengakibatkan tidak tercapainya tujuan yang hendak dicapai.

Strategi dalam sistem pendidikan Islam bertujuan untuk membentuk pola pikir yang islami ('aqliyah Islamiyyah) dan pola sikap yang islami (nafsiyyah islamiyyah), serta membekali peserta didik dengan ilmu pengetahuan yang berhubungan dengan masalah kehidupan. Agar ketiga tujuan tersebut dapat dicapai secara paripurna, maka rancangan kurikulum sebagai bagian dari pendidikan perlu dikedepankan. Dalam hal ini, pendidikan Islam tentunya menghendaki kurikulum yang berlandaskan akidah islamiyah. 
Al-Ḥāzimī menegaskan bahwa proses pendidikan yang dilandasi atas akidah islamiyah dapat mengarahkan jiwa seseorang menuju kondisi yang tentram, ${ }^{3}$ yaitu kondisi kejiwaan yang tidak dapat diwujudkan melalui cara yang lain. Allah menciptakan manusia untuk beriman dan menyatakannya dalam bentuk ibadah, kecintaan, dan keluh-kesah do'a yang ditujukan hanya kepadaNya. Maka dengan mengingat Allah, hati dan jiwa menjadi tenang. ${ }^{4}$ Situasi jiwa yang demikian merupakan implikasi dari pendidikan yang berasaskan akidah islamiyah. Orang yang memiliki akidah yang kuat dipastikan memiliki keyakinan bahwa apapun yang menimpanya tidak dapat mencederainya, dan apapun yang hendak mencederainya tidak akan menimpanya kecuali dengan izinNya. Tidak ada yang lebih utama bagi "yang memiliki akidah yang kuat" melainkan keridaan terhadap qada' dan qadarNya. ${ }^{5}$ Kekuatan rajä' (rasa harap) dan khawf (rasa takut) orang semacam ini berimbang (tawā̃un), sehingga dalam situasi apapun ia dapat menguasai dirinya sendiri.

\section{Strategi Pendidikan Islam: Sebuah Tawaran}

Pada dasarnya tidak ada perbedaan antara metode (termasuk strategi dan teknik) dalam pendidikan Islam dengan pendidikan lainnya. Jika diperhatikan, perbedaannya hanya terletak pada nilai spiritual dan mental yang menyertainya pada saat metode tersebut dilaksanakan atau dipraktikkan. ${ }^{6}$ Nilai spiritual dan mental tersebutlah yang membangun akhlak mulia (akhlakul karimah) dalam diri manusia, karena dalam konteks pendidikan Islam, tujuan pendidikan yang paling krusial adalah menanamkan akhlak mulia dan memerangi kebejatan moral. ${ }^{7}$ Dengan

3Lihat, Qs. Al-Anfāl (8):2. Keimanan yang dimiliki oleh seorang hamba mempengaruhi jiwa menjadi tenang (itmi’nān) yang pada akhirnya merambah pada kelenturan jiwa dan raga untuk ber-amar ma'ruf dan nahi munkar. Pengaruh ini dapat diLihat, dalam Qs. Āli 'Imrān (3):114.

${ }^{4} \mathrm{Khālid}$ bin Hamīd al-Hāzimī, Ușūl al-Tarbiyah al-Islāmiyyah (Madinah: Dār 'Alam al-Kutub, 2000), 31.

IIbid.

${ }^{6}$ Moh. Roqib, Ilmu Pendidikan Islam: Pengembangan Pendidikan Integratif di Sekolah, Keluarga, dan Masyarakat (Yogyakarta: LKiS, 2009), 95.

${ }^{7} \mathrm{Hasan}$ Ibn 'Alī Ibn Hasan al-Hajjàjī, al-Fiker al-Tarbawi 'Inda Ibn alQayyim (Jiddah: Dār Hậạ li al-Nashr wa al-Tawzì', 1988), 164. 
demikian, pendidikan Islam dapat diklaim sebagai pendidikan yang paling ideal. Islam tidak hanya bermaksud mendidik manusia untuk sekadar memiliki wawasan kognisi yang luas, memiliki kehidupan yang sejahtera dan diakuisisi di tengahtengah masyarakat. Namun yang paling penting adalah bagaimana manusia mampu mengintegrasikan kecerdasan intelektual dan kesejahteraan yang telah dianugerahkan tersebut diintegrasikan dengan kecerdasan emosional dan spiritualnya.

Sebagai sebuah tawaran, ada beberapa strategi pendidikan Islam yang layak dipertimbangkan untuk direaktualisasikan dalam dunia pendidikan global saat ini, yaitu sebagai berikut:

\section{Niat Ibadah: Proses Awal dalam Kegiatan Pendidikan}

Bila diperhatikan dalam kebanyakan karya ulama' klasik, sesungguhnya pembahasan niat menempati posisi pertama dalam karya-karya mereka terutama di bidang pendidikan. Imam Nawawi misalnya dalam "Ā dāb al-'Álim wa al-Muta'allim” yang mengawali pembahasannya dengan "Fasl fi al-Ikblàs wa al-Ṣidqi wa I ḥdār al-Niyyati fi Jamīi al-A'māl al-Bārizati wa al-Khafiyyah" (Pasal tentang ikhlas, jujur dan menghadirkan niat dalam setiap aktivitas nyata dan maya). ${ }^{8}$ Adapun al-Zarnūjī dalam karya fenomenalnya "Ta'lim al-Muta'allim" menempatkan pembahasan niat di pembahasan kedua setelah membahas epistemologi ilmu dan fikih serta kelebihannya. Ia mengemukakan bahwa niat merupakan akar, permulaan setiap perbuatan. ${ }^{9}$ Meskipun di urutan kedua, al-Zarnùjī menegaskan bahwa dalam proses menuntut ilmu, niat merupakan tahap pertama yang harus dilalui.

Niat menjadi strategi awal yang urgen dalam setiap aktivitas, termasuk dalam kegiatan pendidikan. Berhasil atau tidak, banyak atau sedikit manfaat yang diperoleh dalam suatu pendidikan sangat ditentukan oleh niat. Imam Nawawi sangat meyakini bahwa niat memiliki kekuatan tersendiri dalam keberhasilan

${ }^{8}$ Al-Imām al-Nawāwī, Adāb al-'Alim wa al-Muta'allim (Ṭanta: Maktabat al-Sahābah, 1987), 7.

'Al-Zarnùjī, Ta'tìm Al-Muta'allim (Surabaya: Al-Miftāh, tt.), 9. 
suatu usaha. Ia terdoktrin oleh perkataan Abdullāh bin 'Abbās sebagai berikut: ${ }^{10}$

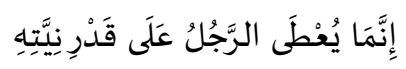

Artinya: Sungguh seseorang akan menuai keberhasilan sesuai kadar (kekuatan) niatnya.

Niat dalam bahasa Arab merupakan bentuk masdar (kata benda) dari kata "nawā-yanwi-niyyatan/niyatan". Dalam Lisān al'Arab diterjemahkan sebagai "arah yang dituju". Al-Jawharī menterjemahkan kata "niyat"sebagai arah yang dituju oleh seorang musafir baik dari jauh maupun dekat. ${ }^{11}$ Dalam terminologi syar'i, niat berarti keinginan melakukan ketaatan kepada Allah dengan melaksanakan perbuatan atau meninggalkannya.

Dalam tataran praktis, niat berperan dalam memberi makna dan hukum bagi pelaksanaan suatu amal atau perbuatan. Ia adalah faktor penentu sah atau tidak suatu perbuatan. ${ }^{12}$ Betapa banyak perbuatan yang terlihat seperti perbuatan akhirat, namun tidak mendapatkan manfaat lantaran niat yang buruk. Demikian pula sebaliknya, betapa banyak perbuatan yang terlihat perbuatan dunia, namun lantaran niat yang baik, manfaatnya dapat diperoleh. Oleh karena itu, al-Qardhawi mengamini hadis tersebut sebagaimana yang dikutip oleh Surur :

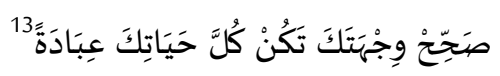

Artinya: Perbaiki niatmu, niscaya seluruh hidupmu menjadi ibadah.

Dalam hal ini, pendidik harus mengingatkan peserta didiknya bahwa pendidikan tidak hanya semata-mata untuk mewujudkan tujuan yang bersifat duniawi semisal mendapatkan pekerjaan atau pun jabatan untuk memenuhi kebutuhan dasar dan akuisisi masyarakat, namun pendidikan diniatkan sebagai salah satu ibadah untuk mencari keridaanNya sekaligus sebagai tugas

${ }^{10}$ al-Nawāwī, Adāb..., 7.

${ }^{11}$ Ibn Manzūur, Lisān al-'Arab, Jilid VI (Kayro: Dār al-Ma'ārif, tt.), 4589.

${ }^{12}$ Al-Imām Abî al-Husayn Muslim ibn al-Hajjāji al-Qushairī alNaysābūrī, Șahịh Muslim, Jilid 2 (Bayrūt: Dār al-'Ilmiyyah, 1991), 1515.

${ }^{13}$ Mishbahus Surur, Dahsyatnya Shalat Tasbih (Jakarta: Quantum Media, 2009), 28. 
kekhalifahan "wajib" dari Allah untuk mengelola bumi dan semua isinya dengan ilmu pengetahuan.

Tidak hanya peserta didik yang harus melandasi aktivitas belajarnya dengan niat ikhlas, tetapi pendidik pun harus melandasi aktivitas mengajarnya dengan ikhlas pula. Bahkan ia harus lebih dahulu mengaplikasikannya sebelum peserta didiknya. Jika pendidik menilai tugasnya dari segi materi semata dan sekadar mencari gaji belaka. Hal tersebut dipandang dapat melunturkan nilai-nilai pendidikan atau bahkan merusak citra dan kemuliaan seorang pendidik.

Bersatunya energi niat ibadah pendidik dan peserta didik dalam proses pembelajaran diharapkan mampu menjadi kekuatan "paripurna" dalam pembentukan kepribadian peserta didik. Oleh karena itu niat ibadah dalam proses membelajarkan harus dilaksanakan dengan ikhlas. Keikhlasan merupakan dasar ibadah agar diterima Tuhan. Hakikat ibadah bukan hanya bersifat nyata, namun juga "maya" semisal ikhlas yang tidak diketahui oleh siapa pun kecuali pribadi yang bersangkutan, karena keikhlasan memancar dari dasar hati. ${ }^{14}$

Pendidikan sebagai bagian dari ibadah dapat ditilik dari definisi yang kemukakan oleh Ibnu Taimiyah bahwa ibadah merupakan nama seluruh perbuatan yang dicintai dan diridai Allah baik berupa perkataan maupun perbuatan. Sehingga, ibadah tidak sebatas ibadah yang lazim seperti shalat, puasa dan sebagainya, namun lebih luas dari itu termasuk menuntut ilmu yang diniatkan ibadah. ${ }^{15}$

Ibadah secara terminologi meliputi penyembahan (al'ubüdiyah), tunduk (al-khudü), dan pasrah (al-zill). ${ }^{16}$ Jika demikian, menuntut ilmu merupakan bentuk kepatuhan atau ketundukan manusia kepada Allah. Juga sebagai bentuk pengagungan kepadaNya. Artinya, perbuatan tersebut memang didedikasikan

${ }^{14}$ Fawziyah Amīn Khayyāt, al-Ahdāf al-Tarbawiyyah al-Sulükiyyyah inda Syaykh al-Islām Ibn Taymiyyah (Makkah al-Mukarramah: Maktabat al-Manārah, 1978), 162.

15al-Hāzimī, Ușūl..., 252.

16‘Adnān Tharshān, Manusia yang Dicintai dan Dibenci Allah: Kunci-kunci menjadi Kekasih Allah, ter. Vivi Sofia Anita (Bandung: Mizan Pustaka, 2008), 71. 
hanya untuk Allah semata. Menurut al-Jarjānī, ibadah adalah perbuatan seorang mukallaf yang berseberangan dengan hawa nafsunya sebagai pengagungan kepada Tuhannya. ${ }^{17}$ Dalam definisi tersebut terdapat relasi antara ibadah dan pendidikan, yaitu pendidikan "Islam" bertujuan untuk membentuk mukallaf yang senantiasa mampu membendung hawa nafsunya.

Dilihat dari segi fasilitas yang dibutuhkan, maka pendidikan yang diniatkan sebagai ibadah dapat dikategorikan ibadah badaniyah, rühiyah mäliyah. Pendidikan memerlukan pengorbanan jiwa, raga dan harta. Kemapanan jiwa diperlukan karena pendidikan merupakan proses berfikir, kekuatan raga atau jasmani dibutuhkan karena pendidikan merupakan aktivitas kenetis, dan kekayaan, walaupun ia tidak mutlak diperlukan karena pendidikan dapat saja dinikmati misalnya melalui beasiswa, yang kadang jumlahnya sangat terbatas. Tepat bila Imam Shafi'i berkata sebagaimana yang dikutip oleh al-Zarnūjī sebagai berikut:

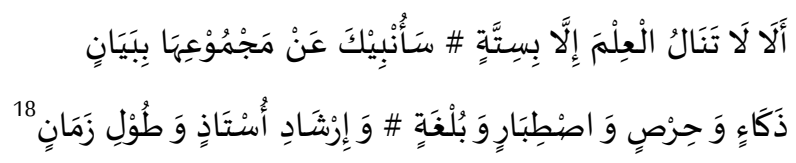

Artinya: Ingatlah! Kamu tidak akan mendapatkan ilmu kecuali dengan 6 perkara. Saya akan menyebutkan seluruhnya dengan jelas; cerdas, tamak (cinta ilmu), sabar, harta, petunjukkan guru (pendidik) dan waktu yang lama.

Mengawali aktivitas pendidikan dengan niat ibadah kerap dilupakan. Proses ini oleh sejumlah pendidikan dianggap remeh. Padahal pendidikan yang diniatkan ibadah menurut Abdurraḥmān Al-Naḥlāw̄i memiliki manfaat yang banyak. Di antaranya sebagai berikut: ${ }^{19}$

1) Dalam konsep Islam, melalui ibadah menusia diajari untuk memiliki intensitas kesadaran berpikir. Dilihat dari segi syaratnya, ibadah yang diterima Allah adalah ibadah yang memiliki dua syarat, yaitu: (a) keikhlasan dan ketaatan kepada

${ }^{17} \mathrm{Al}-\mathrm{Sharīf}$ 'ATi ibn Muḥammad Al-Jarjānī, Al-Ta'rîfät (Sanqāfūrah: AlHaramayn, tt.), 146.

${ }^{18} \mathrm{Al}$-Zarnujī, Ta'tim..., 16.

19'Abdurraḥman Al-Naḥlāwī, Pendidikan Islam di Rumah, Sekolah, dan Masyarakat, ter. Shihabun (Jakarta: Gema Issani Press, 1995), 63-8. 
Alllah; (b) Pelaksanaan ketaatan sesuai dengan cara yang dilakukan Rasulullah Saw, yang di dalamnya terdapat kontinuitas dalam ketundukan kepada Allah, perenungan atas keagungan-Nya dan perasaan patuh kepada-Nya.

2) Melalui kegiatan yang ditujukan semata-mata untuk ibadah kepada Allah, seseorang akan selalu merasa terikat oleh ikatan yang berkesadaran, sistematis, kuat, serta didasarkan atas perasaan jujur dan kepercayaan diri.

3) Dalam Islam ibadah dapat mendidik jiwa seorang muslim untuk merasakan kebanggaan dan kemuliaan terhadap Allah.

4) Ibadah yang terus menerus dilakukan dalam kelompok yang padu dapat melahirkan rasa kebersamaan, sehingga antara individu yang satu dengan lainnya terdorong untuk saling mengenal, saling menasehati, dan bermusyawarah untuk mencari ridaNya.

5) Dalam hal ini, al-Nahlawi juga mengutip pendapat Sayyid Qutub dalam kitabnya Manhaj at-Tarbiyyah al-Islämiyyah, yang menyatakan bahwa melalui ibadah, seorang muslim pun akan terdididk untuk memiliki kemampuan dalam melakukan berbagai keutamaan secara konstan dan mutlak. Artinya setiap gerak seorang muslim tidak terbatas pada batasan geografis, bangsa, kepentingan nasional atau partai yang berkuasa.

Jadi, dalam proses pendidikan, seorang pendidik hendaknya "memasang" niat dalam hatinya bahwa proses pendidikan yang hendak dilaksanakan merupakan ibadah, yang bertujuan mengharapkan ridaNya, menghilangkan kebodohan, menghidupkan agama (iby $\bar{a}^{\prime}$ al-dìn), dan melestarikan Islam (ibq $\bar{a}^{\prime}$ al-Isläm), karena Islam hanya akan berjaya dengan ilmu pengetahuan. ${ }^{20}$ Di samping itu, pendidikan juga diniatkan untuk menegakkan kebenaran, melenyapkan kezaliman, dan sebagai "medan" juang dalam membina mental dan moral serta memelihara kemaslahatan umat.

${ }^{20} \mathrm{Al}$-Zarnūjī, Ta'tìm... 9. 


\section{Pendidikan Berorientasi Masa Depan}

"Allimù awlädakum gayra mā ta'allamtum, fa innabum khuliqū lizamāni gayri zamānikum'"1 - Ajarilah anak-anakmu sebaik-baik apa yang telah kamu pelajari, karena sesungguhnya mereka diciptakan untuk masa yang berbeda dengan masa kalian. Demikian perkataan Ali bin Abi Thalib yang sangat menarik untuk ditilik kembali.

Jika diperhatikan perkataan Imam Ali di atas, sesungguhnya ia ingin menegaskan bahwa pendidikan harus berorientasi pada masa depan. Suhartin mengamini pendapat Sayyidina Ali di atas. Menurutnya, mendidik yang benar harus menjangkau ke depan karena pendidikan ditujukan untuk masa depan anak. ${ }^{22}$ Kondisi sosial dan budaya yang bakal ditemui oleh peserta didik, tidaklah sama dengan kondisi hari ini. Tantangan yang akan mereka hadapi tentu tidak sama dengan masa sekarang. Kehidupan manusia penuh dengan dinamika perubahan di segala lini. Kondisi ini pun "memprotes" keras proses pendidikan yang stagnan, kemudian merekomendasikan proses yang dinamis dan progresif. Sehingga kegiatan membelajarkan akan terus berkembang ke arah antisipatif, yaitu orientasi masa depan. ${ }^{23}$ Oleh karena itu sistem pendidikan yang berorientasi masa depan berarti sistem pendidikan tersebut "mengingat" masa yang sudah lewat, "melihat" keadaan sekarang, dan "menginginkan" masa depan yang dicita-citakan. ${ }^{24}$

Pendidikan yang "berorintasi masa depan" salah satunya dapat dicapai dengan pemahaman yang benar dari para pendidik terhadap tugas dan fungsinya. Pemahaman yang baik dari para pendidik mengenai kewajiban yang harus dilaksanakan pada saat

${ }^{21}$ Mājid 'Arsān Kaylānī, Ahdāf al-Tarbiyyah al-Islāmiyyah (Al-Madīnah alMunawwarah, 1988), 48. Dalam literatur lain menggunakan "khayra" (bukan gayra) dan tanpa menggunakan "mà ta'allamtum". Walau berbeda antara satu referensi dengan lainnya dalam hal lafal, akan tetapi makna substansinya tidak hilang. Bahkan saling menguatkan pesan yang ingin disampaikan, yaitu pendidikan berorientasi masa depan.

22R. I. Suhartin, Smart Parenting (Jakarta: Gunung Mulia, 2010), 26.

${ }^{23}$ Tim Pengembang Ilmu Pendidikan FIP-UPI, Ilmu dan Aplikasi Pendidikan, Bagian 2 (Jakarta: Grasindo, 2007), 3.

${ }^{24}$ Jusuf Amir Feisal, Reorientasi Pendidikan Islam (Jakarta: Gema Insani Press, 1995), 75. 
membelajarkan pendidik, dapat mengarahkan kepada efektivitas kegiatan belajar mengajar, baik di kelas (in door) maupun di luar kelas (out door). Pendidik dengan corak orientasi masa depan akan mempersiapkan diri sebelum pembelajaran dimulai. Dia mendesain rencana pembelajaran terlebih dahulu, seperti merencanakan materi yang disampaikan, matode yang digunakan, waktu yang diperlukan, media yang dibutuhkan, dan referensi yang digunakan.

\section{Memperhatikan Tugas dan Kewajiban Sebagai Seorang Pendidik}

Menjadi pendidik tidak sebatas menyampaikan, namun harus memperhatikan tugas dan kewajibannya sebagai seorang pendidik, yang profesional, yang mendedikasikan seluruh jiwanya untuk pendidikan. Dalam konteks pendidikan Islam, alGhazali menjelaskan tentang tugas dan kewajiban seorang pendidik dalam kitab fenomenalnya "ibyā 'Ulüm al-dìn"25 di antaranya sebagai berikut:

Pertama, memberikan kasih sayang kepada peserta didik dan

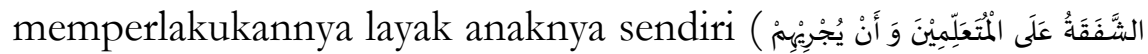
(مَجْرى بَنْيْهِ Salah satu etika pendidik dalam Islam, sebagaimana yang dijelaskan dalam sirah nabäwiyyah adalah pendidik bersikap lembut kepada pelajar, membimbingnya, dan memperlakukannya seperti perlakuan bapak terhadap anaknya. ${ }^{26}$ Seorang pendidik sudah seharusnya menjadi pengganti dan wakil kedua orang tua anak didiknya, yaitu mencintai anak didiknya seperti anaknya sendiri. Perlakukan yang demikian diharapkan dapat menjembatani hubungan psikologis antara pendidik dengan anak didiknya seperti hubungan naluriah antara kedua orang tua dengan anaknya. Sehingga, hubungan timbal balik yang harmonis tersebut akan berpengaruh positif terhadap proses pendidikan dan pengajaran.

Demi terjalinnya harmonisasi di antara pendidik dan peserta didik, maka hubungan di antara keduanya harus mengarah kepada tujuan-tujuan instrinsik pendidikan, yaitu bagaimana

${ }^{25}$ Al-Imām Abī Hamīd Muḥammad bin Mụ̣ammad Al-Gazālī, Ihyā 'Ulūm al-Dìn (Bayrūt: Dār Ibn Hazm, 2005), 68-81.

${ }^{26}$ Sa’ād Riyāḍ, Jiwa dalam Bimbingan Rasulullah, ter. Abdul Hayyie alKattani, dkk. (Jakarta: Gema Insani Press, 2007), 41. 
peserta didik memiliki akhlakul karimah, memiliki kognisi yang mumpuni serta dapat dimanfaatkan dalam kehidupannya. Di samping itu hubungan tersebut terbebas dari tujuan-tujuan ekstrinsik yang bersifat pamrih untuk kepentingan pribadi pendidik $^{27}$, seperti mementingkan gaji daripada menunaikan kewajibanya, mengeksploitasi peserta didik dengan tujuan-tujuan tertentu dan sebagainya.

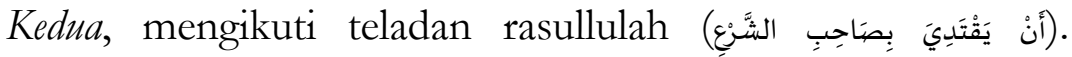
Adapun syarat bagi seorang pendidik, maka ia layak menjadi ganti Rasullulah Saw., dialah sebenar-benarnya 'alim (berilmu, intelektual). Tetapi tidak pulalah tiap-tiap orang yang 'alim itu layak menempati kedudukan sebagai ganti Rasullulah Saw. itu. Dengan demikian seorang pendidik hendaknya menjadi wakil dan pengganti Rasulullah yang mewarisi ajaran-ajarannya dan memperjuangkan dalam kehidupan masyarakat. Demikian juga perilaku, perbuatan, dan kepribadian seorang pendidik harus mencerminkan ajaran-ajarannya, sesuai dengan akhlak Rasullulah karena memang beliau dilahirkan di dunia ini adalah sebagai "uswatun hasanah atau figur ideal" bagi umat pada umumnya dan bagi seorang pendidik pada khususnya.

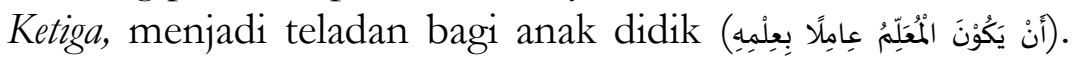
Al-Ghazali mengatakan: "Seorang pendidik harus mengamalkan ilmunya, lalu perkataannya. Karena sesungguhnya ilmu itu dapat dilihat dengan mata hati. Sedangkan perbuatan dapat dilihat dengan mata kepala." Perkataan tersebut menjadi kritik tajam bagi pendidik yang memiliki "muka dua", yaitu berbuat tidak sesuai dengan apa yang telah ia ajarkan. Pendidik hendaklah mengamalkan seluruh yang diajarkannya. Bila hal itu perintah agama, ia laksanakan. Jika hal itu berupa larangan, ia pun menjauhinya. Ia senantiasa mengamalkan semua ilmu pengetahuan yang diajarkannya, karena tindakan dan perbuatan pendidik adalah teladan bagi anak didiknya.

Keempat, tidak menjelek-jelekekan guru mata pelajaran lainnya ( أَنْ

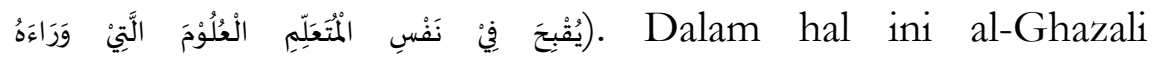
merekomendasikan pendidik untuk menegakkan kode etik guru.

27Prayitno, Dasar-dasar Teori dan Praksis Pendidikan (Jakarta: Grasindo, 2009), 111. 
Dalam UU Nomor 20 tahun 2003 tentang Sisdiknas, kode etik guru berisi norma dan etika yang mengikat perilaku guru dalam pelaksanaan tugas keprofesionalannya. ${ }^{28} \mathrm{Di}$ antaranya adalah tidak pantas seorang pendidik menghina, menjelek-jelekkan pendidik lainnya dengan maksud dan tujuan tertentu, baik dengan kalimat nyata maupun sindiran.

\section{Menciptakan dan Membina Komunikasi yang Baik}

Di antara kunci pelaksanaan strategi pendidikan menurut konsep islami di antaranya adalah melalui komunikasi (tablig) yang baik, yaitu menjalin komunikasi yang harmonis dan rasional dengan peserta didik. ${ }^{29}$ Ditinjau dari prosesnya, pendidikan adalah komunikasi. Artinya, dalam proses tersebut terlibat dua komponen yang terdiri atas pendidik sebagai komunikator dan peserta sebagai komunikan. Bahkan Driyarkara memahami pendidikan sebagai tindakan komunikatif. Menurutnya pendidikan tidak lain merupakan sebuah proses komunikasi yang autentik antarmakhluk yang berada. Pendidikan merupakan komunikasi eksistensia manusiwi yang autentik kepada manusiamuda supaya dimiliki, dilanjutkan, dan disempurnakan. ${ }^{30}$ Jadi komunikasi dalam dunia pendidikan adalah persoalan yang lazim, yang harus dilakukan dengan aktif di antara pendidik dan peserta didik.

Proses pendidikan yang komunikatif diharapkan dapat menghasilkan komunikasi dua arah. Situasi seperti ini dapat terjadi apabila peserta didik bersikap responsif, dan mengetengahkan pendapat atau mengajukan pertanyaan jika diminta atau tidak diminta. Jika peserta didik besikap pasif, mereka hanya sekadar mendengarkan tanpa ada gairah untuk mengekspresikan gagasannya dalam bentuk pernyataan atau pertanyaan, tetap saja berlangsung satu arah sekalipun komunikasi tersebut bersifat tatap muka. Komunikasi semacam

${ }^{28}$ Tim Redaksi, Undang-undang Republik Indonesia Nomor 20 Tabun 2003 tentang Sisdiknas dan Undang-undang Republik Indonesia nomor 14 Tabun 2005 tentang Guru dan Dosen (Jakarta: Transmedia Pustaka, 2008), 78.

${ }^{29}$ Roqib, Pendidikan..., 5.1

${ }^{30}$ Doni Koesoema A., Pendidikan Karakter: Stategi Mendidik Anak di Zaman Global (Jakarta: Grasindo, 2007), 62. 
ini tentu tidak efektif. Oleh karena itu, pendidik hendaknya menyampaikan pelajaran dengan bahasa yang mudah, dan berusaha agar anak didiknya dapat memahami pelajaran. Dalam hal ini, pendidik harus memahami kondisi psikis dan fisik peserta didik, serta mengetahui tingkat kemampuannya dalam berbahasa.

Sebagaimana yang telah dijelaskan di atas bahwa proses pendidikan pada hakikatnya adalah proses komunikasi, yaitu proses penyampaian pesan dari sumber pesan (komunikator) melalui saluran atau media kepada penerima pesan (komunikan). Dalam proses pembelajaran, pesan yang akan dikomunikasikan adalah materi pelajaran ataupun didikan yang ada di dalam kurikulum. Adapun sumber pesannya bisa pendidik, siswa, orang lain ataupun penulis buku. Media atau salurannya dapat berupa media pendidikan semisal audio, audio visual dan sebagainya, sedangkan penerima pesan adalah peserta didik atau dapat juga pendidik itu sendiri (take and give).

Secara teknis Roqib mengemukakan bahwa pesan berupa isi ajaran dan didikan yang ada di kurikulum dituangkan oleh pendidik atau sumber lain ke dalam simbol-simbol komunikasi baik simbol verbal (kata-kata lisan ataupun tertulis) maupun simbol non verbal atau visual. Proses penuangan pesan ke dalam simbol-simbol komunikasi itu disebut encording. Sedangkan proses penafsiran simbol-simbol komunikasi yang mengandung pesan-pesan tersebut disebut decoding. ${ }^{31}$

Penciptaan komunikasi yang baik oleh pendidik kepada peserta didiknya tidak terlepas dari cara komunikasi yang diajarkan oleh Rasulullah Saw. Nabi berkomunikasi dengan memperhatikan kondisi lawan komunikasinya baik fisik maupun psikisnya. Misalnya komunikasi Rasulullah dengan anak yang telah dewasa dilakukan dengan senda gurau sesuai dengan kondisi mereka. Dalam satu riwayat diceritakan:

${ }^{31}$ Roqib, Pendidikan..., 70. 


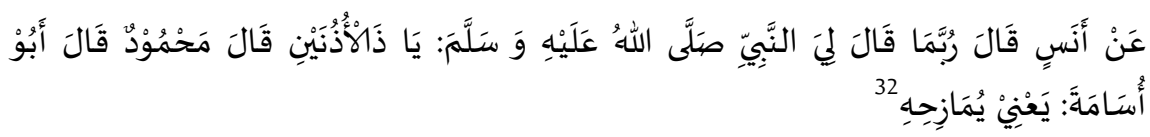

Artinya: Dari Anas berkata: "Kadang-kadang Sesungguhnya Rasulullah Saw. bersabda kepadaku (Anas bin Mālik),'Wahai pemilik dua telinga.' Selanjutnya Abū Usāmah berkata, 'Maksudnya (Rasulullah) bersenda gurau.

Selain memperhatikan kondisi fisik dan psikis peserta didik dalam berkomunikasi, pendidik juga harus sebisa mungkin berkomunikasi dengan bahasa yang jelas, benar, dan tepat. ${ }^{33}$ Rasulullah Saw. mencontohkannya dalam sebuah hadis yang diriwayatkan oleh istrinya Siti 'Aisyah, "bahwa Rasulullah Saw. berbicara dengan jelas dan teratur sehingga setiap orang yang mendengarnya dapat mengerti apa yang beliau katakan."34

Kreativitas Tinggi: Menjadi Pendidik yang Paripurna

Kreativitas adalah kemampuan untuk menciptakan atau menghasilkan sesuatu yang baru. Tim Pustaka Familia mengemukakan enam contoh definisi kreativitas, namun yang paling komprehenship adalah yang keenam, yaitu kemampuan seseorang untuk mengahsilkan komposisi, produk atau gagasan apa saja pada dasarnya baru sebelumnya tidak dikenal pembuatnya. ${ }^{35}$ Jadi kreativitas pendidik dapat difahami sebagai tindakan kreatif pendidik dalam membelajarkan peserta didiknya.

Orang-orang yang kreatif memiliki kebebasan dalam berfikir dan bertindak namun tetap dalam kontrol etika dan estetika. Pendidik adalah salah seorang yang memiliki kebebasan yang berasal dari diri sendiri, termasuk di dalamnya kemampuan untuk mengendalikan diri dalam mencari alternatif yang memungkinkan untuk mengaktualisasikan potensi kreatif yang dimilikinya baik dalam menggunakan metodologi maupun ilmu

${ }^{32} \mathrm{Ab} \overline{1}$ 'Īsā Muhammad bin 'Īsā bin Sawrat al-Tirmidhī, Jāmi' al-Tirmdhi, Hadis ke 3828 (Riyad: Bayt al-Afkār al-Dawliyyah, tt.), 594.

${ }^{33}$ Bunda Fathi, Mendidik Anak dengan al-Qur'an Sejak Janin (Bandung: Pustaka Oasis, 2011), 12.

${ }^{34} A b \bar{u}$ Dāwūd Sulaymān bin Al-Ash'ath Al-Sajastānī, Sunan Abì Dāwūd (Riyaḍ: Bayt al-Afkār al-Dawliyyah, tt.), 526.

${ }^{35}$ Tim Pustaka Familia, Warna-warni Kecerdasan Anak dan Pendampingnya (Yogyakarta: Kanisius, 2006), 252. 
didaktik dalam proses belajar mengajar, sehingga tidak terpaku dan terjebak dalam satu teori belaka. Kemampuan semacam inilah yang menjadikan pendidik yang kreatif berbeda dengan pendidik lainnya (tidak kreatif). Juga, pendidik kreatif selalu merasa tidak cukup bila hanya menyampaikan materi saja. Ia selalu berfikir bagaimana cara agar pembelajarannya berkualitas dan dapat diterima dengan mudah oleh peserta didik. ${ }^{36}$ Tidak ada jalan lain bagi pendidik kecuali berusaha menjadi pendidik yang kreatif.

Tugas seorang pendidik tidak semata-mata memindahkan ilmu pengetahuan (domain kognitif) nilai-nilai atau sikap (domain afektif) dan keterampilan (domain psikomotor), akan tetapi pendidik juga bertugas untuk; pertama, merencanakan program pembelajaran; kedua, mengelola proses pembelajaran; ketiga, menilai proses hasil belajar; keempat, mendiagnosis berbagai masalah yang ditemukan dalam proses pembelajaran, dan kelima memperbaiki program pembelajaran. ${ }^{37}$ Tugas dan fungsi yang demikian kompleks mustahil dicapai optimal, bila para pendidik tidak memiliki kreativitas yang tinggi. Oleh karena itu kreativitas pendidik merupakan suatu keharusan. Dukungan teknologi yang demikian canggih saat ini menjadi "batu sandungan" bahwa tidak ada alasan bagi pendidik untuk mengelak dari tuntutan kreativitas pendidikan.

Dalam tataran praktis, kreativitas boleh jadi bukan merupakan hasil proses berpikir yang disengaja, tetapi suatu anugerah yang diberikan Allah Swt. kepada siapapun yang dikehendaki. Anugerah itu berupa potensi awal yang bersifat positif untuk berkembang. Para ahli agama menyebutnya sebagai fitrah, yaitu suatu potensi yang bersifat suci, positif, dan siap berkembang mencapai puncaknya, yang di dalamnya terdapat potensi-potensi fisik, pikir, rasa dan spiritual. Namun perlu diingat bahwa fitrah (potensi kreativitas) tersebut akan tumpul bila tidak memiliki kehidupan yang variatif, tidak mau memahami diri sendiri, enggan bertanya, tidak memiliki rencana 133.

${ }^{36}$ Mulyana A.Z., Rahasia Menjadi Guru Hebat (Jakarta: Grasindo, 2010),

${ }^{37}$ Soedijarto, Landasan dan Arah Pendidikan Nasional Kita (Jakarta:. Kompas Media Nusantara, 2008), 209. 
dan tujuan hidup, dan tidak mengikuti perkembangan zaman. ${ }^{38}$ Masalah-masalah tersebut kemudian diperparah dengan sikap pendidik yang "acuh tak acuh" terhadap pentingnya nilai kreativitas dalam pendidikan. Bukankah Islam mengajarkan pemeluknya untuk menjadi manusia yang kreatif? Ungkapan Tuhan di dalam al-Qur'an dengan bahasa khalaqa, ansha'a dan fatara yang berarati menciptakan, ja'ala yang berarti menjadikan, zayyana yang bermakna menghiasi, dan kata semisal lainnya, cukuplah menjadi dalil nyata bahwa Islam memiliki perhatian yang besar terhadap aksi-aksi kreatif, terlebih dalam pendidikan.

\section{Mendidik dengan Keteladanan: Mencontoh Akblak Rasulullab}

Al-Qur'an telah memberikan contoh bagaimana manusia belajar lewat meniru. Kisah tentang Qabil yang dapat mengetahui bagaimana menguburkan mayat saudaranya Habil yang telah dibunuhnya, diajarkan oleh Allah dari meniru seekor gagak yang menggali-gali tanah guna menguburkan bangkai seekor gagak yang lain. ${ }^{39}$ Kecenderungan manusia untuk meniru belajar lewat peniruan, menyebabkan keteladanan menjadi sangat penting artinya dalam pendidikan. ${ }^{40}$

Rasulullah adalah suri tauladan yang ideal bagi umat manusia. Sahabat dalam setiap kesempatan berusaha mencontoh sikap, cara dan akhlak beliau. Kemampuan Rasulullah mendidik sahabat-sahabatnya dengan keteladanan memberi side effects yang besar dalam membentuk karakter mereka. Menurut Al-Nadawī, tingkat keberhasilan yang dicapai Rasulullah dalam membangun karakter kemanusiaan belum pernah dicapai oleh seorang nabi, pembaharu, dan pendidik dari masa sebelumnya. ${ }^{41} \mathrm{Hal}$ inilah yang menjadi salah satu alasan bagi Michael $H$. Hart menempatkan Rasulullah sebagai tokoh pertama dari seratus tokoh yang berpengaruh di dunia, dalam buku monumentalnya "The 100: A Ranking of the Most Influential Persons in History".

${ }^{38}$ Hernowo, Menjadi Guru yang Mau dan Mampu Mengajar Secara Kreatif (Bandung: MLC, 2007), 29-39.

${ }^{39}$ Lihat, Qs. al-Māidah (4):31.

40'Adnān Hasan Șālih, Tanggung Jawab Ayah Terhadap Anak Laki-laki, ter. Sihabuddin (Jakarta: Gema Insani Press, 1996), 54.

${ }^{41}$ Abū al-Hasan 'AlīAl-Nadawī, Ablussunnah dan Syi'ah Menilai Rasulullah, ter. Muhammad F, Nurul Huda (Jakarta: Qalam, 1995), 25. 
Nabi Muhammad sebagai pendidik agung telah memberikan keteladanan kepada umatnya dalam kesempurnaan akhlak ketinggian budi dan keagungannya. ${ }^{42} \mathrm{Di}$ antaranya dapat dikemukan sebagai berikut:

a. Gelar al-Amin (amanah) dan al-Ṣiddiq (benar) yang disandingkan kepada Rasulullah Saw. oleh bangsa Arab pada saat itu menjadi bukti kejujuran dan kebenaran ucapan yang tidak terbantahkan.

b. Sifat fatānah (cerdas) yang diberikan kepada Rasulullah Saw. tidak lantas menjadikannya orang yang ambisi terhadap jabatan dan popularitas. Padahal ia pernah disuap oleh kafir Quraisy untuk melepaskan kenabiannya. Kemudian ia dijanjikan akan diangkat menjadi raja dan diberikan harta berlimpah, namun semua itu ditolak.

c. Dari segi ibadah, Rasulullah Saw. adalah al-insān al-kamīl yang menghabiskan waktunya untuk beribadah kepadaNya, hingga kakinya menjadi bengkak dan menghitam, sebagaimana yang diceritakan dalam banyak riwayat.

d. Dalam hal kedermawanan, Rasulullah Saw. adalah orang yang pemurah, sangat dicintai oleh orang-orang miskin dan anak yatim. Dan masih banyak akhlak terpuji lainnya.

Berdoa: Awal dan Akhir Aktivitas Pendidikan

Sebagai makhluk sosial, manusia saling membutuhkan antara yang satu dengan yang lainnya. Hal ini sudah merupakan fitrah manusia. Mereka memohon pertolongan kepada orang yang lebih berkuasa, kepada orang kaya, atau kepada orang yang memiliki kekuasaan jika mereka dalam kesulitan yang tidak dapat diatasi sendiri.

Do'a merupakan penyejuk dan penawar hati yang duka. Ia memiliki kekuatan yang dapat melepas belenggu derita yang dialami manusia. Secara teologis, berdo'a merupakan ibadah yang menghubungkan hati dan pikiran manusia dengan Tuhannya, yang mungkin dilakukan di awal, sewaktu atau sesudah keinginan terkabul ataupun usaha terlaksana sesuai keinginan.

42Lihat, Qs. al-Aḥzāb (33) : 21 dan Qs. al-Qalam (68): 4. 
Islam menganjurkan dan bahkan mewajibkan kepada manusia untuk berdo'a dalam setiap kegiatan yang memiliki manfaat, seperti dalam kegiatan-kegiatan yang berhubungan dengan pendidikan. Secara normatif dan populis, kewajiban berdo'a dapat ditilik langsung dalam firmanNya yang artinya: "Berdo'alab kepada-Ku, niscaya akan kuperkenankan bagimu. Sesunggubnya orang-orang yang menyombongkan diri dari menyembah-Ku akan masuk neraka Jahanam dalam keadaan hina". 43

Do'a bukan berarti sekadar permohonan untuk memperoleh kebaikan dunia dan kebaikan akhirat. Namun, do'a lebih bertujuan untuk menetapkan dan memantapkan langkah-langkah dalam upaya meraih kebaikan yang di maksud, karena do'a diyakini mengandung arti permohonan yang disertai usaha. Jika dalam proses pembelajaran selalu diawali dan diakhiri dengan do'a, bukan hanya material ilmu belaka yang diperoleh, melainkan kemanfaatan dan keberkahan dari ilmu tersebut pun diperoleh. 44

Merujuk esensi do'a di atas, seorang pendidik islami diharapkan dapat mengajak dan memotivasi peserta didiknya untuk berdo'a terlebih dahulu sebelum pembelajaran dimulai, demikian pula sebelum mengakhiri pembelajaran, karena ilmu yang diperoleh merupakan bagian dari nikmat Tuhan. Sehingga berdo'a merupakan salah satu bentuk rasa syukur seorang hamba kepada Tuhannya, dan Dia pasti akan menambah apa yang telah dianugerahkanNya. ${ }^{45}$ Jadi do'a pada hakikatnya memiliki posisi teologis yang strategis dalam proses pendidikan. Do'a memiliki kekuatan yang sulit dijangkau oleh nalar ilmiah manusia, namun positive effect-nya dapat dirasakan nyata semasa dan setelah proses pendidikan itu berlangsung.

\section{Catatan Akhir}

Sebagai catatan akhir dari tulisan ini, perlu diingat bahwa tidak semua konsep "klasik" sifatnya kadaluarsa. Pendidikan

${ }^{43}$ Qs. al-Mu'min (40): 60. Lihat pula, Qs. Al-A' ārf: 55, 29; Qs. alBaqarah (2): 186, 201; Qs. Āli 'Imr ān (3):38; Qs. al-Anbiyā': 87-88; Qs. Nūh: 26, 27, 28.

${ }^{44}$ Lihat, Qs. Yūnus (10): 106.

45Lihat, Qs. Ibrāhīm (14):7. 
Islam misalnya. Walau ia terkesan kolot namun bisa jadi ia merupakan jaminan dan satu-satunya jalan keluar yang dapat ditempuh untuk menghasilkan lulusan yang memiliki intelektual dan moral yang tinggi. Fakta telah berbicara dalam banyak sejarah bahwa pendidikan Islam dengan strateginya yang islami telah mampu melahirkan para ulama' sekaligus ilmuwan yang cerdik pandai. Tidak hanya itu, yang lebih memukau adalah kemampuan mereka mensenergikan ilmu yang dimiliki dengan akhlak yang mulia, karena tidak dapat dipungkiri bahwa keindahan moral seseorang menjadi payung keilmuan dan keintelaktualan yang dimilikinya.

Dapat dibayangkan bagaimana kedaan bumi ini bila hanya dibasahi dengan manusia-manusia cerdas, namun kering moralnya. Maka satu-satunya jalan adalah mengembalikan eksistensi pendidikan Islam dalam kegiatan belajar meengajar. Dalam hal ini strategi pendidikan Islam harus diperkuat dan diaplikasikan secara kontinu (istiqamah) dalam setiap proses pendidikan. Strategi pendidikan Islam yang telah terdokumentasi dalam al-Qur'an, hadis dan karya-karya para ulama' terdahulu, tidaklah elok jika hanya dijadikan sebatas isu belaka, namun strategi pendidikan yang harus terus-menerus dipraktikkan. Sehingga diharapkan strategi pendidikan Islam mampu mengimbangi pendidikan global baik dari segi moral, spiritual maupun mutu pendidikan. Wa al-Lāh a'lam bi al-sawāb.

\section{Daftar Pustaka}

Fathi, Bunda. 2011. Mendidik Anak dengan al-Qur'an Sejak Janin. Bandung: Pustaka Oasis.

Feisal, Jusuf Amir. 1995. Reorientasi Pendidikan Islam. Jakarta: Gema Insani Press.

Al-Gazālī, Al-Imām Abī Hamīd Muhammad bin Muḥammạ̣. 2005. Ihyä' 'Ulüm al-Dìn. Bayrut: Dār Ibn Hazm.

Al-Hajjājì, Hasan Ibn 'Ali Ibn Hasan. 1988. al-Fiker al-Tarbawi 'inda Ibn al-Qayyim. Jiddah: Dār Hāfiz li al-Nashr wa alTawzî̀.

Al-Hāzimī, Khālid bin Hamīd. 2000. Ușūl al-Tarbiyyah alIslämiyyah. Madīnah: Dār 'Ālam al-Kutub. 
Hernowo. 2007. Menjadi Guru yang Mau dan Mampu Mengajar Secara Kreatif. Bandung: MLC.

Al-Ghazālī, Al-Imām Abī Hamīd Muhammad bin Muhammaḍ. 2005. Ibyà' 'Ulūm al-Dìn. Beirut: Dār Ibn Hazm.

Al-Hajjàjīi, Hasan Ibn 'Ali Ibn Hasan. 1988. al-Fiker al-Tarbawi inda Ibn al-Qayyim. Jiddah: Dār Hāâz li al-Nashr wa alTawz $\overrightarrow{1}$.

Al-Hāzimī, Khālid bin Hamīd. 2000. Usūul al-Tarbiyyah alIslämiyyah. Madīnah: Dār 'Ālam al-Kutub.

Al-Jurjānì, Al-Sharîf 'Alī ibn Muḥammad Al-Ta'rîfät (Sanqāfurah: Al-Haramayn, tt.).

Kaylānī, Mājid 'Arsān. 1988. Abdāf al-Tarbiyyah al-Islāmiyyah. AlMadīnah al-Munawwarah.

Khayyāṭ, Fawziyah Riḍā Amīn. 1978. Al-Abdāf al-Tarbawiyyah alSulükiyyah inda Shaykh al-Isläm Ibn Taymiyyah. Makkah alMukarramah: Maktabat al-Manārah.

Koesoema A., Doni. 2007. Pendidikan Karakter: Stategi Mendidik Anak di Zaman Global. Jakarta: Grasindo.

Manzūur, Ibn. tt. Lisān al-'Arab. Jilid VI. Kairo: Dār al-Ma'ārif.

Mulyana A.Z. 2010. Rahasia Menjadi Guru Hebat. Jakarta: Grasindo.

Al-Nadawī, Abū al-Hasan 'Alī. 1995. Ablussunnah dan Syi'ab Menilai Rasulullah, ter. Muhammad F dan Nurul Huda. Jakarta: Qalam.

Al-Nawawī, Al-Imām. 1987. Ādāb al-'Ālim wa al-Muta'allim. Ṭantā: Maktabat al-Sạābah.

Al-Naysābūrī, Al-Imām Abū al-Husayn Muslim ibn al-Hajjājī alQushayrī. 1991. Sahīh Muslim. Jilid II. Beirut: Dār al 'Ilmiyyah.

Prayitno. 2009. Dasar-dasar Teori dan Praksis Pendidikan. Jakarta: Grasindo.

Riyād, Sa'àd. 2007. Jiwa dalam Bimbingan Rasulullah, ter. Abdul Hayyie al-Kattani dkk.. Jakarta: Gema Insani Press.

Roqib, Moh. 2009. Ilmu Pendidikan Islam: Pengembangan Pendidikan Integratif di Sekolah, Keluarga, dan Masyarakat. Yogyakarta: LKiS.

Al-Sajastānī, Abū Dāwūd Sulaymān bin Al-Ash'ath. tt. Sunan Abì Dāwūd. Riyād: Bayt al-Afkār al-Dawliyyah. 
Ṣālị, 'Adnān Hasan. 1996. Tanggung Jawab Ayah Terhadap Anak Laki-laki, ter. Sihabuddin. Jakarta: Gema Insani Press.

Soedijarto. 2008. Landasan dan Arah Pendidikan Nasional Kita. Jakarta: Kompas Media Nusantara.

Suhartin, R. I. 2010. Smart Parenting. Jakarta: Gunung Mulia.

Tafsir, Ahmad. 1994. Ilmu Pendidikan dalam Perspektif Islam. Bandung: Remaja Rosdakarya.

Tharsyan, Adnan. 2008. Manusia yang Dicintai dan Dibenci Allab: Kunci-kunci menjadi kekasih Allah. ter. Vivi Sofia Anita. Bandung: Mizan Pustaka.

Tim Pengembang Ilmu Pendidikan FIP-UPI. 2007. Ilmu dan Aplikasi Pendidikan, Bagian 2. Jakarta: Grasindo.

Tim Redaksi. 2003. Undang-undang Republik Indonesia Nomor 20 Tahun 2003 tentang Sisdiknas dan Undang-undang Republik. Indonesia nomor 14 Tabun 2005 tentang Guru dan Dosen. Jakarta: Transmedia Pustaka.

Tim Pustaka Familia. 2006. Warna-Warni Kecerdasan Anak dan Pendampingnya. Yogyakarta: Kanisius.

Al-Tirmidh̄̄, Abū 'T̄sā Muhammad bin 'Īsā bin Sawrat. tt. Jāmi' al-Tirmdhì. Riyad: Bayt al-Afkār al-Dawliyyah.

Al-Zarnūjī. tt. Ta'lìm Al-Muta'allim. Surabaya: Al-Miftāḥ. 